\title{
Challenging Novelties within the Circular Economy Concept under the Digital Transformation of Society
}

\author{
Milena P. Ilić ${ }^{1, *}\left(\mathbb{D}\right.$, Marko Ranković ${ }^{2}$, Milutin Dobrilović ${ }^{3}$, Rocsana Bucea-Manea-Țoniş ${ }^{4,5} \oplus$, Larisa Mihoreanu ${ }^{6}$, \\ Mădălina Ionela Gheța ${ }^{7}$ and Violeta-Elena Simion ${ }^{8}$ (])
}

1 Information Technology School ITS-Belgrade, LINK Group Belgrade, Faculty of Contemporary Arts Belgrade, University Business Academy, 11000 Belgrade, Serbia

2 Faculty of Information Technology and Engineering, University Union Nikola Tesla, 11080 Belgrade, Serbia; marko.rankovic@fiti.edu.rs

3 Faculty of Economics, University of Belgrade, 11000 Belgrade, Serbia; dobrilovic@ekof.bg.ac.rs

4 Doctoral School, National University of Physical Education and Sport, 060057 Bucharest, Romania; rocsense39@yahoo.com

5 USH Pro Business, Spiru Haret University, 030167 Bucharest, Romania

6 Faculty of Administration and Public Management, Bucharest University of Economic Studies, 010374 Bucharest, Romania; dr.mihoreanu@gmail.com

7 Business Administration Doctoral School, Bucharest University of Economic Studies, 010374 Bucharest, Romania; ghetamadalina@gmail.com

8 Faculty of Veterinary Medicine, Spiru Haret University, 030045 Bucharest, Romania; ushmv_simion.violeta@spiruharet.ro

* Correspondence: milena.ilic@its.edu.rs

check for updates

Citation: Ilić, M.P.; Ranković, M.; Dobrilović, M.; Bucea-Manea-T, Toniş, R.; Mihoreanu, L.; Gheța, M.I.; Simion, V.-E. Challenging Novelties within the Circular Economy Concept under the Digital Transformation of Society. Sustainability 2022, 14, 702. https://doi.org/10.3390/su14020702

Academic Editor: Alessia Amato

Received: 26 October 2021

Accepted: 5 January 2022

Published: 9 January 2022

Publisher's Note: MDPI stays neutral with regard to jurisdictional claims in published maps and institutional affiliations.

Copyright: (C) 2022 by the authors. Licensee MDPI, Basel, Switzerland. This article is an open access article distributed under the terms and conditions of the Creative Commons Attribution (CC BY) license (https:// creativecommons.org/licenses/by/ $4.0 /)$.

\begin{abstract}
The study makes, under a new configuration of the circular economy, a cross-country analysis based on the Competitiveness and Innovation Indicators in the E.U., i.e., two sub-criteria: private investments, jobs, and gross value added; and patents related to recycling and secondary raw materials as a proxy for innovation. The analysis proved that investments influence the number of patents, and participate in societal transformation. A further cluster analysis classified countries on the level of innovation. The cluster analysis in SPSS centres on significant potential, weaknesses, impact, and waste management control through blockchain technology. It is found that the factors that influence innovation, according to the Global Competitiveness Report, link the business dynamism and innovation capability with the capacity to sustain resilient ideas, such as competitive intelligence and social entrepreneurship. The discussions aim to prove that the efforts to rethink the circular economy principles contribute to its conceptual and societal transformation role through the implementation of innovative processes, inventive solutions, and blockchain technologies, and their social consequences to solve environmental problems. Once understood and accepted, CE will drive sustainable behaviour.
\end{abstract}

Keywords: circular economy; competitiveness; investments and patents governance; innovation and policy for sustainability; societal transformation

\section{Introduction}

The circular economy sustains economic return, and strengthens the quality of life through its multiple roles. Its principles can positively impact individuals, establishments, and economies. In 2020, the European Union set up the Action Plan for Circular Economy (CE) as the healthiest way to outline sustainability through respect and responsibility within the environment and society. The circular economy can drive systemic change, and sustain the value circulation within the ecosystem, eliminating the concept of waste. The circular economy represents a model to restore ecosystems. Both innovation and habit-altering define its implicative characteristics [1-4]. 
Many scientists consider the circular economy the best model for societal and economic benefit [1-3]. This is proved as a suitable solution regarding economic and social inequality, and deficient political strategies. If risks are in a falling trend in a country, the country's risk premium is also experiencing a fall, which positively influences society and the national economy [4]. The United Nations and OECD, as institutions of global recognition, highlight the circular economy as a significant social shift towards an original and inherently energetically efficient system; its general implementation will help competitiveness that will sustain the high technology use, and give a more effective response to global ecological challenges.

Digital and competitive intelligence skilled human resources are the driving factor in the circular economy. Adapted innovative human resources with transferable and digital competencies are trained in educational institutions using new technologies, such as blockchain, MOOCs, eXtended Reality (XR), etc. [5,6].

This article aims to analyse the elements of innovation and competitiveness of selected countries within the $\mathrm{CE}$ concept to measure the position of these countries. Firstly, the analysis utilises a regression model that shows that the number of patents correlates with the investments in innovation. Still, additional factors regarding innovation should be analysed. Secondly, we performed a cluster analysis to emphasise which countries are more innovative, and the factors that nudge innovation. This way, with an understanding of current positions, progress on their path to a circular economy and sustainable development could be measured.

Contributions of the study are reflected in measuring the "as is" situation in terms of selected circular economy criteria, identifying obstacles, and making recommendations for further efforts.

\section{Background Research}

The European Commission recommended four leading indicators (production and consumption, waste management, secondary raw material, and competitiveness and innovation) for all European countries to use in their national evaluations to take the appropriate measures to promote a sustainable circular economy [7]. However, although many qualitative types of research were performed on the circular economy, competitiveness, and innovation, only a few studies have quantitatively evaluated the circular economy concept and the elements included in the EU CE fourth indicator, as they are usually chosen as background [8-10].

Đurđević et al. believe that being competitive in the domestic, regional, or world market is set as an aspiration and the goal of doing business for many companies. However, current business conditions on the market impose the need for constant adjustment and a continual search for ways to raise competitiveness for companies. This is precisely because of the overproduction and oversaturation of the market [11-13]. Consequently, companies find it challenging to differentiate and position themselves in consumers' minds (i.e., market positioning). Although it is complex and difficult for companies to achieve competitiveness in the market in the mentioned business conditions, it is not impossible [14]. Ilić and Radnović find that companies constantly have to fight to keep existing leadership positions by winning new ones in the conditions of increased competition in numerous industries. For companies to cope with such increased competition, it is necessary to constantly reinvent and adapt their products and business processes to gain an advantage over the competition, thus securing the "best in class position". Today, it can be argued that innovation, i.e., the introduction and application of new ideas in companies' business across many industries, is a strategic ability. The companies with a low innovation index, i.e., the share of the sales generated by products (processes) existing for less than three years, can be neither competitive nor successful $[15,16]$.

Janssens and the team address the need for quantity and quality competencies that are necessary for a circular transition to occur, and that "transversal competencies and 
valorisation competencies are equally important as technical competencies for a circular economy" [17,18].

The classical meaning of innovation, referring to the creation of new things, is redefined by Stošić as "renewal and expansion of products, services and markets", so those "new ways are set up in management, work organisation, conditions and skills" [19]. Miletić et al. find that innovations enable improved quality of products and services, increase security, and lead to increased competitiveness [20]. Gay and Szostak point out the importance of innovation and creativity for the small- and medium-sized enterprises (SMEs), accounting for more than $90 \%$ of companies worldwide, which have to be creative and innovative to survive in their market, and differ from the competition. They find that SMEs are not the scaled-down versions of large enterprises [21], a view also confirmed by Torres [22]. Adding that they have their specificities and laws and that, despite specific inherent difficulties, SMEs provide a favourable environment for developing creative ideas. However, specific characteristics are preventing them from implementing innovations. Gay and Szostak believe that innovation is of great importance for driving the competitiveness of an enterprise and the growth of a country, which is presented through a dilemma implying that, although necessary, it brings uncertainty, and is complex to understand and implement. The dilemma worries all companies regardless of the company size. The authors, however, note that SMEs are more exposed to uncertainty. Increasing competition and globalisation have put innovation at the forefront of industrial development. A lack of the capacity to successfully manage uncertainty risks is particularly detrimental to small firms [21].

Schiederig et al. identify six characteristics of an eco-environmental innovation as "an object which is characterised by its market orientation, its environmental benefit over its whole life cycle and which sets the innovative green standard to the company even if its primary intention may be environmental or economic" [23].

The technologies' development and innovative implementation in the market cannot be conceived outside societal life. They influence everything: work, development, life. Patents play a significant role in technology, from development as a concept, and marketing as a tool. Moreover, transferring innovative technologies to third parties opens up new development and financial opportunities. Gross domestic spending on research and development is the first link in the innovation chain. An important step has been taken by introducing in the Europe 2020 Strategy the leading indicator "research and development intensity", a measure that refers to the dimensions of production and output of innovation. The share of research and development staff in the workforce reached $1.2 \%$ of total employment in 2015, most of whom were employed in the business field. This was observed in reporting almost half of the EU enterprises' innovation activity in 2014. At the same time, the size of GDP per capita was significant; the states with the largest number of innovative enterprises also had this indicator relatively high. Moreover, one-third of them developed cooperative activities with other enterprises in 2012-2014 [24]. But, it is true that though some countries are spreading technologies [25], others use the know-how generated by other countries [26]. This suggests that research and development is not the only criteria underpinning innovation. Other factors need to be considered. Raghupathi V and Raghupathi W (2017) noted that the association between living standards and innovation suggests that to improve innovation and drive growth, countries need to focus on improving living standards in terms of high minimum wages, and better working conditions. At the same time, they point out that countries with high foreign patents have low tax revenues as a percentage of GDP, and this income is mobile. Patent ownership can be found in locations other than the country in which they were created [27]. Through answers to some questions about the proportion of patented innovations, the pace and continuity of this process in a country, how patenting affects the dissemination of knowledge, etc., Mosser shows that innovation measures are not influenced by local patenting [28]. Having a solid patent system is not the essential development policy for low- and middle-income countries, as Bronwyn H. (2020) shows [29]. According to the observation of Gold et al. (2017), the 
relationship between intellectual property and economic growth is a placebo effect rather than growth, valid locally, both at the level of companies and the macro level [30-33].

\section{Experimental Data, Complex Analysis, and Significant Results}

\subsection{Data and Variables}

The European Commission recommended four leading indicators for European countries to use in their national evaluations to take the appropriate measures to promote a sustainable circular economy. These are [7]:

- The production and consumption indicator-consider households' and economic sectors' waste product, which has to be reduced as much as possible. It is measured through green public procurement, and the quantity of waste generation and food waste to reach self-sufficiency of raw materials for production in the EU [7].

- Waste management indicator-based on the reuse-recycle-repair principle to create value from treated waste, and is measured by two determinants: recycling rates; and specific waste streams, such as packaging waste, biowaste, e-waste, etc. [34].

- Secondary raw materials indicator-recycled materials bring added value once reintroduced into the economy circuits, saving natural resources consumption, mitigating the environmental footprint, and offering a continuous supply of raw materials. It is evaluated through the contribution of recycled materials to raw materials demand, and the trade of recyclable raw materials between the EU member states [28,35].

- Competitiveness and innovation indicator-creates continuously new types of jobs and sustainable activities, green forms of products, industries, agriculture. Innovation in technology, raw material, design, production, and methodology will facilitate the reuse of waste. Private investments, jobs, gross value added, and patents related to recycling and secondary raw materials as a proxy for innovation. The private investment and patents will be analysed in this paper.

The authors chose to analyse the competitiveness and innovation EU CE indicator, collecting Eurostat data [7] regarding the average investment (private investments, jobs and gross value added related to circular economy sectors-CEI_CIE010) and patents (patents about recycling and secondary raw materials-CEI_CIE020) for 2012-2018, by country in EU (Appendix A). We chose 2012 as the starting date for the analysis, referring primarily to the situation in Romania. In 2012, the industrial production stagnated after 2010, and in 2011, it registered uninterrupted increases, according to the National Institute of Statistics [36]. We then looked at how this aspect is found at the European level. Furthermore, in the following few years, the worldwide growth rate of gross world product fell to the lowest level since the global financial crisis, with significant losses, especially in the period 2014-2015. For example, in 2016, 49 countries saw a decline in per capita income [37].

Nevertheless, global growth reached $3.1 \%$ in 2017-the fastest pace since 2011. Subsequently, due to increased investment in several sectors of activity, the world economy experienced a revival. The United States, for example, was supported in 2018 by a fiscal expansion that offset the deficit of other economies [37].

\subsection{Research Process}

The analysis is based on public statistical data available, accessed and collected from the European official statistics databases (Eurostat WEF, Balance Innovation scorecard). In addition, we also accessed national authorities' data to understand the dynamics and impact of the CE policies in selected countries (Appendix A, Table 2). Finally, figures were used to present the descriptive statistics of the analysed data (Figure 1). 


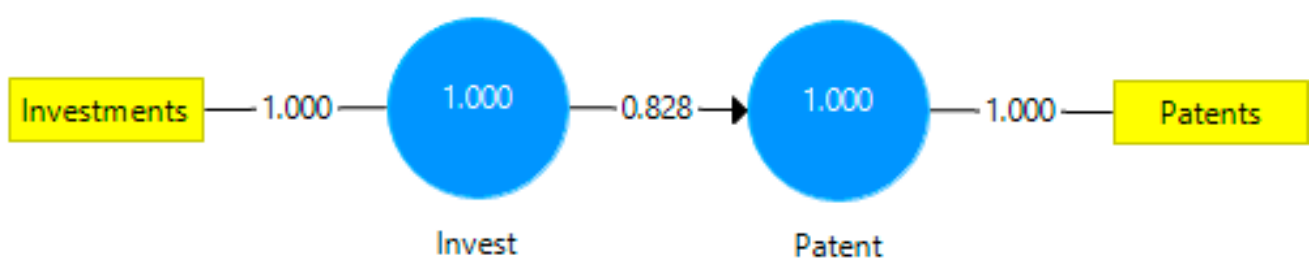

Mean, STDEV, T-Values P Values

\begin{tabular}{|c|c|c|c|c|c|}
\hline & Original Sample... & Sample Mean... & Standard Deviation ... & T Statistics... & P Values \\
\hline Invest -> Patent & 0.828 & 0.825 & 0.104 & 7.929 & 0.000 \\
\hline
\end{tabular}

Figure 1. Composite reliability coefficient.

Based on the data presented, we intend to prove the following hypotheses:

Hypothesis 1 (H1). The level of investments influences the number of patents to some extent.

Hypothesis 2 (H2). The innovation level differs in EU countries mainly due to different levels of investments, but other factors might be analysed (such as cultural factors).

In the first stage, a regression model was designed to evaluate the influence of investment over the number of patents in CE in 24 of the EU countries. Because of Eurostat's lack of reported data, Liechtenstein, Norway, Switzerland, Czech Republic, Ireland, Luxembourg, Malta, and Iceland were not included. These innovation patents, which now require $10 \%$ of ROI, will bring in the future $70 \%$ of ROI, proving the future sustainable impact of innovation on the economy [38-41].

In the second stage, for a clear insight into the impact of innovation on the sustainable economy in the EU, a cluster analysis was designed using the K-means algorithm, and each cluster's characteristics, challenges, weaknesses, and strengths in obtaining sustainable innovation were emphasised.

\subsection{The First Stage-Regression Analysis for Evaluation Relations between Investments and Patents}

Firstly, a regression model emphasising the importance of investments in innovation on increasing the number of patents for the EU applied to the fourth CE indicator will be used to obtain the CE outcomes in the EU. Our analysis excludes Liechtenstein, Norway, Switzerland, Czech Republic, Ireland, Luxembourg, Malta, and Iceland because they do not provide data on our variable. A strong positive correlation (0.828) is identified between the model's two variables (invest and patent). This correlation allows the authors to design the regression model. The $\mathrm{R}^{2}$ coefficient is 0.68 , indicating that the variation of causal investment variable determines $68 \%$ of the variable patent variance, and the model cannot explain $32 \%$ of this influence. As $\mathrm{R}^{2}$ is not very close to 1 , in a future analysis, we have to add some other factors that influence the number of patents, such as culture, technical facilities (hardware, software), the accuracy of knowledge, etc. Finally, the F-statistic offers arguments supporting or rejecting the null hypothesis (H0). Having a low value (0.00), the probability of making a mistake if accepting $\mathrm{H} 1$ is minimal. Thus, $\mathrm{H} 1$ is proven (the level of investments influences the number of patents).

$\mathrm{R}^{2}(0.67)$ 's adjusted value is also close to the value of $\mathrm{R}^{2}$, which proves that the influence of the independent variable (invest) is significant, and explains the variance of the dependent variable (patent). Since the adjusted $R^{2}$ value is close to the value of $R^{2}$, this allows the extension of the proposed regression model to the entire population surveyed. In this case, the variance of the dependent variable decreases with the difference between the two coefficients $(0.685-0.671=0.015)$. This difference can be seen to be below $1 \%$. The 
$t$-test generated for the invest variable validates the model, and contributes to the predictive power of regression. The variables' significance threshold (Sig.) should be less than or around 0.05 . In our case, Sig. 0.00 is lower than 0.01 for investment, meaning that the coefficient of this variable is very well estimated, and Sig. 0.44 for constant is higher than 0.05 , meaning that the constant could be better estimated.

Durbin-Watson's statistic strengthens the model, showing no autocorrelation between variables. Durbin-Watson tests the null hypothesis that residuals are not linearly autocorrelated. Though the test can take values between 0 and 4 , the values around 2 indicate no autocorrelation. As a rule, values of $1.5<\mathrm{d}<2.5$ show no autocorrelation in the data. The VIF value helps us make the collinearity diagnostics. If the VIF value is greater than 3 , there is a chance of multi-collinearity between independent variables. If this value is above 5 , then the chances of multi-collinearity are high. If this value is over 10, the independent variables indeed show multi-collinearity. In this case, the VIF is 1, meaning there is no collinearity between variables. In conclusion, the present model is valuable.

The regression equation it might be seen below (Tables 1-3):

$$
\text { Patent }=2.194+1.861 \times 10^{-3} \times \text { Invest }
$$

Table 1. Regression results-Pearson Correlations *.

\begin{tabular}{cccc}
\hline & & Invest & Patent \\
\hline Invest & Pearson Correlation & 1.000 & 0.828 \\
& Sig. (2-tailed) & 0.0 & 0.000 \\
Patent & N & 24 & 24 \\
& Pearson Correlation & 0.828 & 1.000 \\
& Sig. (2-tailed) & 0.000 & 0.0 \\
& $\mathrm{~N}$ & 24 & 24 \\
\hline
\end{tabular}

* Correlation is significant at the 0.01 level (2-tailed).

Table 2. Model Summary.

\begin{tabular}{|c|c|c|c|c|c|c|c|c|c|}
\hline \multirow[t]{2}{*}{$\mathbf{R}$} & \multirow[t]{2}{*}{ R Square } & \multirow[t]{2}{*}{$\begin{array}{l}\text { Adjusted } \\
\text { R Square }\end{array}$} & \multirow[t]{2}{*}{$\begin{array}{l}\text { Std. Error of } \\
\text { the Estimate }\end{array}$} & \multicolumn{2}{|c|}{ Change Statistics } & \multirow[b]{2}{*}{ df1 } & \multirow[b]{2}{*}{ df 2} & \multirow[b]{2}{*}{ Sig. F Change } & \multirow[t]{2}{*}{$\begin{array}{l}\text { Durbin- } \\
\text { Watson }\end{array}$} \\
\hline & & & & R Square Change & F Change & & & & \\
\hline 0.828 & 0.685 & 0.671 & 11.428 & 0.685 & 47.861 & 1 & 22 & 0.000 & 1.668 \\
\hline
\end{tabular}

Table 3. Coefficients.

\begin{tabular}{cccccccc}
\hline & $\begin{array}{l}\text { Unstandardized } \\
\text { Coefficients }\end{array}$ & B & $\begin{array}{c}\text { Standardized } \\
\text { Coefficients }\end{array}$ & T & Sig. & $\begin{array}{c}\text { Collinearity } \\
\text { Statistics }\end{array}$ & Tolerance \\
\hline & B & Std. Error & Beta & & & VIF \\
\hline (Constant) & 2.194 & 2.812 & & 0.780 & 0.444 & & 1.000 \\
\hline INVEST & $1.861 \times 10^{-3}$ & 0.000 & 0.828 & 6.918 & 0.000 & 1.000 \\
\hline
\end{tabular}

Dependent Variable: PATENT.

Table 2 shows model Summary for the regression equation.

Table 3 presents Coefficients for the regression equation.

Furthermore, the authors used SmartPLS 3.0 software to calculate the composite reliability coefficient. The coefficient of composite reliability analysis strengthens our hypothesis, and shows good internal consistency because it is higher than the accepted limit of 0.7. In our case (Figure 1), the coefficient is 1 for both variables: investment and patent. Furthermore, the path coefficient $(0.828$ higher than 0.7$)$ and $p$-Value $(0.00$ smaller than 0.1 ) and a very low standard deviation (0.09) also empowers us to consider that the model is very reliable. 


\subsection{The Second Stage-K Means Cluster Analysis}

Secondly, a cluster analysis was performed to emphasise which countries are more innovative, and the factors that nudge innovation [42-44]. Studying the two criteria (patent, invest), one may observe that countries such as Italy (cluster 1), France (cluster 2), and Spain (cluster 6) form clusters by themselves (Table 4). France has almost the same number of patents as Poland, but France receives a higher investment amount. Spain and Italy have a small number of patents, under the average. Spain must review their innovation policy because of such low results while receiving a larger number of investments. Countries such as Belgium, Netherlands, Austria, Poland, and Sweden form cluster 3, representing the average sample: they have a medium investment amount and a medium number of patents. However, in this cluster, three countries, mainly the Nordic countries, show a higher degree of innovation due to significant investment, competitive human resources, and cultural background: pro-innovation attitude and the leadership mentality, which urges them to be creative, and find solutions in hostile environments. Germany and the United Kingdom (UK) form cluster 4 because they have a high investment, but the highest number of patents are obtained by Germany, being the most innovative European country. The complex infrastructure, technology, pro-innovation attitude, and competitive spirit make the difference in Germany's case. There is no doubt that the same countries show outstanding digitalisation and competitive intelligence outputs. This helps market actors to easier amass, study, and use information from all the fields of the market-competitors, decision-makers, or customers. Other countries, such as Romania, represent the extreme side, and form cluster 5. The low level of investment received reflects a small number of patents $[45,46]$. Still, other very complex factors are challenging to measure in figures/numbers, such as cultural patterns, self-esteem, lack of perspective, and lack of accurate and useful information that keep these countries far from innovation [46-48].

Table 4. Cluster membership, based on both criteria, Patents and Invest.

\begin{tabular}{cccccc}
\hline COUNTRY & Cluster & Distance & COUNTRY & Cluster & Distance \\
\hline Italy & 1 & 0.000 & Denmark & 5 & $1,414,072$ \\
\hline France & 2 & 0.000 & Finland & 5 & $1,149,118$ \\
\hline Belgium & 3 & $1,349,409$ & Cyprus & 5 & 674,931 \\
\hline Netherlands & 3 & $1,501,600$ & Estonia & 5 & 607,931 \\
\hline Austria & 3 & 668,430 & Latvia & 5 & 591,929 \\
\hline Poland & 3 & 489,102 & Portugal & 5 & 529,071 \\
\hline Sweden & 3 & 29,544 & Lithuania & 5 & 454,932 \\
\hline Germany & 4 & $1,385,379$ & Romania & 5 & 364,075 \\
\hline U.K. & 4 & $1,385,379$ & Slovenia & 5 & 332,934 \\
\hline Spain & 6 & 0.000 & Bulgaria & 5 & 317,934 \\
\hline & & & Croatia & 5 & 262,936 \\
\cline { 3 - 5 } & & & Greece & 5 & 200,939 \\
\cline { 3 - 5 } & & & Slovakia & 5 & 196,930 \\
\cline { 3 - 5 } & & & Hungary & 5 & 185,074 \\
\hline
\end{tabular}

\section{Discussion}

The European Union conducted a competitiveness and innovation analysis based on Eurostat data: the eco-innovation index, R\&D staff, and the product and innovative process enterprise (with its sub-criteria/items). Investments in human resources, and proper management of life cycle assessments (LCAs), based on blockchain technology, created new business models and innovations that ensured a sustainable economy. This assumption was validated by a regression model and K-means analysis [46]. We show that R\&D promotes HR creativity, innovation, and collaboration, which positively affect eco-innovation and sustainable development. Product- and process-innovative companies have a limited impact on eco-innovation. We continue our previous research with this current article. The regression analysis shows a strong and positive correlation between 
investment and patents $(0.828$ - when the investments increase by 1 unit, the number of patents increases by 0.828 units). Finally, the European Union countries were grouped based on investment and patent numbers in clusters. The results showed that all countries in cluster 5 have a poor track record of innovation. In contrast, clusters 3 and 4 countries are more innovative, having a good infrastructure, competitive human resources, and a pro-innovation culture [47-49].

The good and bad sides of how waste management and energy consumption are currently dealt with and treated are subjected to analyses and recommendations for future solutions. Promoting the CE indicators represents a recommended solution, to be woven into all educational programs in everyday communication until they become a concept familiar to all citizens, changing their mindset through ecological sustainability. Data analytics, digital technologies, and competitive intelligence are essential facilitators of the circular economy, changing development towards social entrepreneurship [47]. Competitive innovation sustains the idea that learning from what is happening inside and outside the business box helps increase both competitiveness and chances for catching any new opportunities. The more one understands, the bigger the profit and the chances to overcome competitors, satisfying customers, and facilitating operational management development for society and the environment. This also contributes to a new design of entrepreneurship to combine the classical and modern professions, develop new ways of business, and speed up decisions linked to environment preservation.

Executive decisions and societal wellbeing [48-51] could help those countries suffering because of insufficient investment, limited access to knowledge, and other constraints that stop their move for a better and more-accomplished life. Here, social entrepreneurs have an important word to say and a challenging task for the circular economy to drive the next level of development and impact their future.

Although this research has shown a strong positive correlation between investments and innovation, using the number of patents as proxy, the creation of patents solely does not guarantee their usability or an economic return or contribution to societal development. Indeed, there are many patents and innovations that never reach the market due to unfavourable economic and business conditions. An object of further study would be to assess the quality of patents, and their impact on society and the economy, as it is difficult to quantify the impact of these patents on the circular economy. It is indeed possible that some technologies prove to be unsustainable, and rather hinder the progress to a circular economy. As this study has only explained part of the causes of innovation growth through investments, further factors that affect this should be identified and included.

\section{Conclusions}

The CE influences national economies, organisations, and consumers. Given that fact, each actor participating in either social or business life, and every representative nominated by the Government, has to find their respective role and interest in sustainable behaviour to reach Green Deal objectives.

The regression model shows that investment proved the most crucial factor that stimulates patents in CE innovation. However, some other elements deserve to be added to the model for a sustainable economy, such as creating new jobs in the green economy, governmental support, green public procurement, education for understanding, and the implementation of digital and transferable knowledge and competencies.

Based on quantitative and qualitative analyses, the paper helps better understand Romania's current situation regarding innovation and competitiveness.

Some results confirm the hypotheses: (a) the level of investments influences the number of patents to some extent; (b) the innovation level differs in EU countries due to investment and cultural factors. Therefore, if Romania has an intention to approach the EU average, it has to increase in investments, which will be reflected in the number of patents and technology transfers, which would bring numerous benefits to the economy and society, as well as to sustainable development. 
The importance of the article is subjective. However, the authors are highly motivated for their home countries to take a better course in their transition from linear to circular to follow the results of other countries in the lead. Sustainability is neither a race nor a competition; it might be a run through different shades of interest in science and professional education. Executive decisions considering societal wellbeing could help those countries in suffering because of insufficient investment, limited access to knowledge, and other constraints that stop their move for a better and more-accomplished life. Here, social entrepreneurs have an important word and a challenging task for the circular economy to drive the next level of development and impact their future. And they could be assisted by competitive intelligence to unlock the creation of new frameworks; help align targets, activities, and operations across information systems; and increase the speed of circular economy transformation into a resilient cornerstone for both people and society.

Author Contributions: Conceptualisation, M.P.I., M.R., M.D., R.B.-M.-T., L.M. and V.-E.S.; methodology, R.B.-M.-T., L.M. and V.-E.S.; software, R.B.-M.-T. and L.M.; validation, M.I.G. and V.-E.S.; formal analysis, R.B.-M.-T.; investigation, M.P.I., M.I.G. and R.B.-M.-T,; resources, M.P.I. and R.B.-M.-T.; data curation, R.B.-M.-T.; writing—original draft preparation, M.P.I., M.R., M.D., M.I.G., R.B.-M.-T,., L.M. and V.-E.S.; writing-review and editing, M.P.I., M.R., M.D., M.I.G., R.B.-M.-T., L.M. and V.-E.S.; visualisation, L.M., M.I.G. and M.D.; supervision, M.D.; project administration, V.-E.S.; funding acquisition, M.P.I. All authors have read and agreed to the published version of the manuscript.

Funding: This research received no external funding.

Institutional Review Board Statement: Not applicable.

Informed Consent Statement: Not applicable.

Data Availability Statement: The data are available on request from the corresponding author.

Conflicts of Interest: The authors declare no conflict of interest.

\section{Appendix A. Average of Investment and Patents for 2012-2018, by Country in EU}

Table A1. Average of Investment and Patents for 2012-2018, by country in EU.

\begin{tabular}{ccc}
\hline Country & Investments & Patents \\
\hline Belgium & 2856,585714 & 10,79428571 \\
Bulgaria & 530,2142857 & 0,642857143 \\
Denmark & 2262,257143 & 4,097142857 \\
Germany & 29732,47143 & 86,87714286 \\
Estonia & 240,4 & 0,804285714 \\
Greece & 646,9166667 & 0,428571429 \\
Spain & 11221,92857 & 25,29142857 \\
France & 21276,82857 & 43,99142857 \\
Croatia & 585,4714286 & 0,504285714 \\
Italy & 17974,21429 & 21,32 \\
Cyprus & 173,46 & 0,471428571 \\
Latvia & 255,6857143 & 1,628571429 \\
Lithuania & 392,5714286 & 0,827142857 \\
Hungary & 1033,085714 & 3,46 \\
Netherlands & 5708,085714 & 15,59714286 \\
Austria & 3537,657143 & 9,47 \\
Poland & 4695,042857 & 38,02714286 \\
Portugal & 1376,857143 & 2,488571429 \\
Romania & 1211,785714 & 4,092857143 \\
Slovenia & 514,8285714 & 0,635714286 \\
Slovakia & 650,9142857 & 1,8 \\
Finland & 1996,9 & 12,75857143 \\
Sweden & 4234,271429 & 5,308571429 \\
\hline
\end{tabular}




\section{References}

1. Franco-García, M.; Carpio Aguilar, J.-C.; Bressers, H.T. Towards Zero Waste-Circular Economy Boost, Waste to Resources; Springer International: London, UK, 2019.

2. Tonelli, M.; Cristoni, N. Strategic Management and the Circular Economy; Routledge: London, UK, 2019.

3. Stahel, W. The Circular Economy A User's Guide; Routledge: London, UK, 2019.

4. Petrović, D.; Ilić, M.; Ranković, M.; Dobrilović, M. Calculation of the Risk of Investment in Southeast European Countries by Applying the CAPM Model. Vision 2025: Education Excellence and Management of Innovations through Sustainable Economic Competitive Advantage. In Proceedings of the International Business Information Management Conference (34th IBIMA), Madrid, Spain, 13-14 November 2019; pp. 1600-1603.

5. Guustaaf, E.; Rahardja, U.; Aini, Q.; Maharani, H.; Santoso, N. Blockchain-based Education Project. Aptisi Trans. Manag. ATM 2021, 5, 46-61. [CrossRef]

6. Yumna, H.; Khan, M.M.; Ikram, M.; Ilyas, S. Use of Blockchain in Education: A Systematic Literature Review. In Proceedings of the 11th Asian Conference on Intelligent Information and Database Systems, ACIIDS 2019, Yogyakarta, Indonesia, 8-11 April 2019; Part II, pp. 191-202.

7. Eurostat. Circular Economy Indicators. Available online: https://ec.europa.eu/eurostat/web/circular-economy/indicators (accessed on 15 February 2021).

8. Grafström, J.; Siri, A. Breaking circular economy barriers. J. Clean. Prod. 2021, 292, 126002. [CrossRef]

9. Hysa, E.; Kruja, A.; Naqeeb, R.; Laurenti, R. Circular Economy Innovation and Environmental Sustainability Impact on Economic Growth: An Integrated Model for Sustainable Development. Sustainability 2020, 12, 4831. [CrossRef]

10. Trica, C.L.; Banacu, C.S.; Busu, M. Environmental Factors and Sustainability of the Circular Economy Model at the European Union level. Sustainability 2019, 11, 1114. [CrossRef]

11. Laurenti, R.; Singh, J.; Frostell, B.; Sinha, R.; Binder, C.R. The Socio-Economic Embeddedness of the Circular Economy: An Integrative Framework. Sustainability 2018, 10, 2129. [CrossRef]

12. Lazarevic, D.; Valve, H. Narrating expectations for the circular economy: Towards a common and contested European transition. Energy Res. Soc. Sci. 2017, 31, 60-69. [CrossRef]

13. Bucea-Manea-Țoniș, R.; Dourado Martins, O.M.; Ilic, D.; Belous, M.; Bucea-Manea-Țoniș, R.; Braicu, C.; Simion, V.-E. Green and Sustainable Public Procurement-An Instrument for Nudging Consumer Behavior. A Case Study on Romanian Green Public Agriculture across Different Sectors of Activity. Sustainability 2020, 13, 12. [CrossRef]

14. Đurđević, D.; Radnović, B.; lić, M. Organizacija marketing logistike u funkciji tržišne konkurentnosti. Posl. Ekon. 2017, 11, 165-183.

15. Ilić, M.; Radnović, B. Inoviranje u Turizmu kao način Obezbeđenja Konkurentske prednosti, sa Konkretnim Primerima. Quality Festival Kragujevac. 2008. Available online: http:/ /www.cqm.rs/2008/pdf/35/27.pdf (accessed on 4 January 2022).

16. Brydges, T. Closing the loop on take, make, waste: Investigating circular economy practices in the Swedish fashion industry. J. Clean. Prod. 2021, 293, 126245. [CrossRef]

17. Hull, C.E.; Millette, S.; William, E. Challenges and opportunities in building circular-economy incubators: Stakeholder perspectives in Trinidad and Tobago. J. Clean. Prod. 2021, 296, 126412. [CrossRef]

18. Janssens, L.; Kuppens, T.; Schoubroeck, S.V. Competences of the professional of the future in the circular economy: Evidence from the case of Limburg, Belgium. J. Clean. Prod. 2021, 281, 125365. [CrossRef]

19. Stošić, B. Menadžment inovacija u ekonomiji baziranoj na znanju. Manag.-Časopis Za Teor. I Praksu Menadžmenta 2006, 11, 11-16.

20. Miletić, L.; Ilić, M.; Kastratović, E. The role of financial institutions from the aspect of innovated banking products and services as the reply of banks in Serbia to the changes in the environment. Int. Rev. 2018, 1, 111-118. [CrossRef]

21. Gay, C.; Szostak, B. Innovation and Creativity in SMEs; STE Ltd.: London, UK; John Wiley \& Sons, Inc.: Hoboken, NJ, USA, 2019.

22. Torrès, O. Les PME, Tiers État permanent. In Sociétal; Daniel, J.M., Monlouis-Felicité, F., Eds.; Eyrolles: Paris, France, 2017; pp. 58-70.

23. Schiederig, T.; Tietze, F.; Herstat, C. Green innovation in technology and innovation management-An exploratory literature review. RED Manag. 2012, 42, 180-192.

24. Europe 2020 Indicators-R\&D and Innovation. July 2017. Available online: https://ec.europa.eu/eurostat/statistics-explained/ index.php?title=Europe_2020_indicators_-_R\%26D_and_innovation\&oldid=335438 (accessed on 15 November 2021).

25. Wang, E. Determinants of R\&D investment: The extreme-bounds analysis approach applied to 26 OECD countries. Res. Policy 2010, 39, 103-116.

26. Guloglu, B.; Tekin, R.B. A panel causality analysis of the relationship among research and development, innovation, and economic growth in high-income OECD countries. Eurasian Econ. Rev. 2012, 2, 32-47.

27. Raghupathi, V.; Raghupathi, W. Innovation at country-level: Association between economic development and patents. J. Innov. Entrep. 2017, 6, 4. [CrossRef]

28. Moser, P. Patents and Innovation: Evidence from Economic History. J. Econ. Perspect. 2013, 27, 23-44. [CrossRef]

29. Hall, B.H. Patents, Innovation, and Development; NBER Working Paper No. 27203, JEL No. L65,O25,O30,O34; NBER: Cambridge, MA, USA, 2020.

30. Gold, E.R.; Morin, J.-F.; Shadeed, E. Does intellectual property lead to economic growth? Insights from a novel IP dataset. Regul. Gov. 2017, 13, 107-124. [CrossRef] 
31. Fidélis, T.; Saavedra Cardoso, A.; Ri, F.; Catarina Miranda, A.; Abrantes, J.; Teles, F.; Roebeling, P.C. Policy narratives of circular economy in the E.U.-Assessing the embeddedness of water and land in national action plans. J. Clean. Prod. 2021, $288,125685$. [CrossRef]

32. Matthews, C.; Moran, F.; Jaiswalt, A.K. A review on European Union's strategy for plastics in a circular economy and its impact on food safety. J. Clean. Prod. 2021, 283, 125263. [CrossRef]

33. Lacy, P.; Long, J.; Spinder, W. The Circular Economy Handbook, Realising the Circular Advantage; Palgrave Macmillan: London, $\mathrm{UK}, 2020$.

34. Sharma, S.; Basu, S.; Shetti, N.P.; Aminabhavi, T.M. Waste-to-energy nexus for circular economy and environmental protection: Recent trends in hydrogen energy. Sci. Total Environ. 2020, 713, 136633. [CrossRef]

35. Raw Materials Information System. E.U. Science Hub. Available online: https://rmis.jrc.ec.europa.eu/?page=circular-economymonitoring (accessed on 10 September 2021).

36. National Institute of Statistics. Available online: http:/ / www.insse.ro/cms/ro/content/comunicate-de-presa-arhiva (accessed on 19 December 2021).

37. United Nations, Department of Economic and Social Affairs Economic Analysis. World Economic Situation and Prospects: November 2018 Briefing, No. 120. 2018. Available online: https:/ /www.un.org/development/desa/dpad/publication/worldeconomic-situation-and-prospects-november-2018-briefing-no-120 (accessed on 19 December 2021).

38. Rocsana \& Radu Bucea Manea Tonis, Lianu Costin, Gudei Corina, Lianu Cosmin. Inovare si digitalizare din perspectivă managerială. Ed. Economica, 2020. Available online: https://www.librarie.net/p/398233/inovare-si-digitalizare-din-perspectivamanageriala (accessed on 19 December 2021).

39. Yadav, S.; Lenka, U. Diversity management: A systematic review. Equal. Divers. Incl. 2020, 39, 901-929. [CrossRef]

40. Kukenberger, M.R.; D'Innocenzo, L. The building blocks of shared leadership: The interactive effects of diversity types, team climate, and time. Pers. Psychol. 2020, 73, 125-150. [CrossRef]

41. Roh, H.; Chun, K.; Ryou, Y.; Son, J. Opening the Black Box: A Meta-Analytic Examination of the Effects of Top Management Team Diversity on Emergent Team Processes and Multilevel Contextual Influence. Group Organ. Manag. 2019, 44, 112-164. [CrossRef]

42. Pocol, C.B.; Pinoteau, M.; Amuza, A.; Burlea-Schiopoiu, A.; Glogovetan, A.I. Food Waste Behavior among Romanian Consumers: A Cluster Analysis. Sustainability 2020, 12, 9708. [CrossRef]

43. Resti, Y.; Burlian, F.; Yani, I.; Rosiliani, D. Analysis of a cans waste classification system based on the CMYK colour model using different metric distances on the k-means method. J. Phys. Conf. Ser. 2020, 1500, 012010. [CrossRef]

44. Özlem, T.; Turkish, B.S. SMES corporate sustainability approaches: Cluster analysis method, an empirical study. Mediterr. J. Soc. Sci. 2014, 5, 175. [CrossRef]

45. Prokop, V.; Stejskal, J. Different approaches to managing innovation activities: An analysis of strong, moderate, and modest innovators. Eng. Econ. 2017, 28, 47-55. [CrossRef]

46. Bucea-Manea-T,oniş, R.; Šević, A.; Ilić, M.P.; Bucea-Manea-T,oniş, R.; Popović Šević, N.; Mihoreanu, L. Untapped Aspects of Innovation and Competition within a European Resilient Circular Economy. A Dual Comparative Study. Sustainability 2021, 13, 8290. [CrossRef]

47. Kristoffersen, E.; Blomsma, F.; Mikalef, P.J. The smart circular economy: A digital-enabled circular strategies framework for manufacturing companies. J. Bus. Res. 2020, 120, 241-261. [CrossRef]

48. Costea, C. Complexity: New opportunities for understanding consumption. Proc. SPIE 2008, 6802, 9.

49. Profiroiu, A.; Profiroiu, M. Developing Strategic Management Capacity of the Central Government: Limits and Challenges, American Society for Public Administration. In Proceedings of the 2014 ASPA Annual Conference-Celebrating the Success and Promoting the Future of Public Service, Washington, DC, USA, 14-18 March 2014; 2014. Panel: Strategic Management in Public Organizations and Local Communities: Pitfalls and Opportunities. Available online: http://issuu.com/aspanational/ docs/aspa_2014_conference_program (accessed on 15 November 2021).

50. Kuleto, V.; Ilić, M. AI and developing human intelligence, future learning and educational innovation, John Senior and Éva Gyarmathy. Rev. Za Soc. Polit. 2021, 28, 429-446. [CrossRef]

51. Bucea-Manea-Țoniş, R.; Martins, O.M.D.; Bucea-Manea-T,oniş, R.; Gheorghiță, C.; Kuleto, V.; Ilić, M.P.; Simion, V.-E. Blockchain Technology Enhances Sustainable Higher Education. Sustainability 2021, 13, 12347. [CrossRef] 